\title{
Trehalose biosynthesis in Thermus thermophilus RQ-1: biochemical properties of the trehalose-6-phosphate synthase and trehalose-6-phosphate phosphatase
}

Received: 26 April 2004 / Accepted: 4 August 2004/Published online: 29 September 2004

(C) Springer-Verlag 2004

\begin{abstract}
The genes for trehalose synthesis in Thermus thermophilus RQ-1, namely ots A [trehalose-phosphate synthase (TPS)], ots $B$ [trehalose-phosphate phosphatase (TPP)], and tre $S$ [trehalose synthase (maltose converting) (TreS)] genes are structurally linked. The TPS/TPP pathway plays a role in osmoadaptation, since mutants unable to synthesize trehalose via this pathway were less osmotolerant, in trehalose-deprived medium, than the wild-type strain. The ots $A$ and ots $B$ genes have now been individually cloned and overexpressed in Escherichia coli and the corresponding recombinant enzymes purified. The apparent molecular masses of TPS and TPP were 52 and $26 \mathrm{kDa}$, respectively. The recombinant TPS utilized UDP-glucose, TDP-glucose, ADP-glucose, or GDPglucose, in this order as glucosyl donors, and glucose-6phosphate as the glucosyl acceptor to produce trehalose6-phosphate (T6P). The recombinant TPP catalyzed the dephosphorylation of T6P to trehalose. This enzyme also dephosphorylated G6P, and this activity was enhanced by NDP-glucose. TPS had an optimal activity at about $98^{\circ} \mathrm{C}$ and $\mathrm{pH}$ near 6.0; TPP had a maximal activity near $70^{\circ} \mathrm{C}$ and at $\mathrm{pH} 7.0$. The enzymes were extremely thermostable: at $100^{\circ} \mathrm{C}$, TPS had a half-life of $31 \mathrm{~min}$, and TPP had a half-life of $40 \mathrm{~min}$. The enzymes did not require the presence of divalent cations for activity; however, the presence of $\mathrm{Co}^{2+}$ and $\mathrm{Mg}^{2+}$ stimulates both TPS and TPP. This is the first report of the characterization of TPS and TPP from a thermophilic organism.
\end{abstract}

Communicated by G. Antranikian

Z. Silva $\cdot$ S. Alarico $\cdot$ M. S. da Costa $(\square)$

Departamento de Bioquímica and Centro de Neurociências

e Biologia Celular, Universidade de Coimbra,

3004-517 Coimbra, Portugal

E-mail: milton@ci.uc.pt

Tel.: + 351-239-824024

Fax: + 351-239-826798
Keywords Compatible solutes - Thermus thermophilus RQ-1 $\cdot$ Trehalose biosynthesis

\section{Introduction}

The strains of the species Thermus thermophilus have optimum growth temperatures in the neighborhood of $75^{\circ} \mathrm{C}$ and are frequently isolated from marine hot springs. The strains of this species grow in media without added $\mathrm{NaCl}$, but are also capable of growing in media containing up to about $5.0-6.0 \% \mathrm{NaCl}$ (da Costa et al. 2001). Trehalose is the major compatible solute of the strains of $T$. thermophilus during osmotic stress in yeast extract-tryptone- $\mathrm{NaCl}$ medium, while mannosylglycerate accumulates in lower amounts (Nunes et al. 1995). The accumulation of trehalose during osmotic stress by $T$. thermophilus in yeast extract-containing medium is, as in many other organisms, due to its uptake from the medium (Mikkat et al. 1997; Lamosa et al. 1998; Silva et al. 2003). However, some strains of this species are also capable of synthesizing trehalose in a minimal salt-containing medium deprived of exogenous trehalose (Silva et al. 2003).

The nonreducing disaccharide trehalose is formed from two glucose units linked by a $\alpha, \alpha-1,1$-glycosidic linkage. This disaccharide is widespread throughout the biological world, where it serves many functions. It may serve as a carbon and energy reserve, as an intermediate in the synthesis of mycolic acids, and as a signaling molecule to control metabolic pathways. Trehalose is also a very common compatible solute of microorganisms, as it protects proteins and membranes against inactivation or denaturation caused by a variety of stress conditions (Leslie et al. 1995; Santos and da Costa 2002; Elbein et al. 2003; Silva et al. 2003).

Three different pathways for the biosynthesis of trehalose are known. The most common pathway for the synthesis of trehalose in bacteria involves condensation of glucose-6-phosphate (G6P) with UDP-glucose (UDPG), catalyzed by trehalose-phosphate synthase 
[(TPS), the product of the ots $A$ gene] to yield trehalose6-phosphate (T6P). This intermediate is subsequently dephosphorylated to yield trehalose via a specific trehalose-phosphate phosphatase [(TPP) the product of otsB gene, Giæver et al. 1988]. In Saccharomyces cerevisiae, trehalose is synthesized by the same reactions, but the corresponding enzymes, TPS1 and TPS2, form a multimeric synthase complex together with additional regulatory subunits (Reinders et al. 1997). The second pathway converts maltose to trehalose via a trehalose synthase encoded by trehalose synthase (treS). Homologues of treS are known in some bacteria, including T. thermophilus (Tsusaki et al. 1996, 1997; White et al. 1999; De Smet et al. 2000; Wolf et al. 2003). A third pathway is found in several bacteria (Maruta et al. 1995, 1996a, b; De Smet et al. 2000) and the hyperthermophilic archaeon Sulfolobus acidocaldarius (Maruta et al. 1996c). This pathway uses polyglucose to generate trehalose via maltooligosyltrehalose (MOT) synthase encoded by tre $Y$ and by MOT trehalohydrolase encoded by treZ. Some organisms may possess one, two, or even the three of the pathways (De Smet et al. 2000; Wolf et al. 2003). Osmoregulated trehalose synthesis appears to involve TPS and TPP in some organisms, but a recent report associates the accumulation of trehalose during osmotic adjustment to the TreYZ pathway in Corynebacterium glutamicum, which contains the genes for the other two pathways, as well (Wolf et al. 2003).

We recently cloned and sequenced the genes associated with trehalose biosynthesis in $T$. thermophilus RQ1. In this strain the ots $A, o t s B$, and tre $S$ genes are structurally linked. An otsA/otsB deletion mutant of strain RQ-1 only grew in a defined $\mathrm{NaCl}$-containing medium with $3 \% \mathrm{NaCl}$, whereas the wild type grew in the medium with $5 \% \mathrm{NaCl}$. This mutant only accumulated mannosylglycerate, which appears to play a role in low-level osmotic adjustment of T. thermophilus (Santos and da Costa 2002; Silva et al. 2003). The addition of trehalose to the medium restored osmotic tolerance, but maltose did not, implying that the latter disaccharide could not be converted to trehalose via TreS. This work provided crucial evidence for the importance of TPS/ TPP pathway for the synthesis of trehalose during osmoadaptation of T. thermophilus RQ-1 and showed that trehalose was the primary compatible solute of this organism (Silva et al. 2003). The present work concerns the detailed characterization of TPS and TPP in $T$. thermophilus RQ-1 and is the first to report the characteristics of these enzymes in a thermophilic organism.

\section{Materials and methods}

Cloning of ots $A$ and ots $B$ from Thermus thermophilus RQ-1

Thermus thermophilus RQ-1 chromosomal DNA was isolated as previously described (Marmur 1961). The otsA gene (GenBank accession number AY275558) was amplified from $T$. thermophilus RQ-1 genomic DNA, using the forward primer TPS009 (5'-GCG GAATTCATGGGGCTCATCATCG- $\left.{ }^{\prime}\right)$ and the reverse primer TPS002 (5'-GCG CTGCAGTCATCCCTCCTCCAAGGAGGC-3'). These primers were designed to include an EcoRI site (underlined) upstream of the start codon (boldface) and a $P s t \mathrm{I}$ restriction site (underlined) downstream of the stop codon (boldface). The amplified gene ots $A$ was ligated into and EcoRI- and PstI-digested pKK223-3 (Amersham Biosciences) expression vector to obtain pKKTPS.

The ots $B$ was cloned as a fusion gene with gluthatione-S-transferase (GST). The GST gene, and the thrombin cleavage site was obtained from plasmid pEG(KG) (Mitchell et al. 1993) digested with SacI and $X b a \mathrm{I}$. The $0.7-\mathrm{kb} S a c \mathrm{I} / X b a \mathrm{I}$ fragment was cloned into the same sites of pTRC99A (Pharmacia Biotech), yielding pTRC99A-GST. The otsB gene (GenBank accession number AY 275558) was amplified from RQ-1 chromosomal DNA, using the forward primer GST1 (5'GCG GGATCCATGAGGGCGGAAAACCCCG-3') and the reverse primer GST2 (5'-GCG TCTAGACTAAAGGCTAGTGGGTCG-3'). These primers were designed to include a BamHI site (underlined) upstream of the start codon (boldface) and a $X b a \mathbf{I}$ restriction site (underlined) downstream of the stop codon (boldface). Gene otsB and pTRC99A-GST plasmid were digested with Bam HI and XbaI and ligated to transform Escherichia coli XL1-blue. The resulting clones containing plasmid pTRC99A-GSTPP were selected for ampicillin resistance. The constructions bearing the ots $A$ gene (pKKTPS) or otsB gene (pTRC99AGSTPP) were used to transform an E. coli BL-21 Rosetta strain (Novagen, Madison, Wis., USA) that carries tRNA genes for rare codons. PCR amplifications were carried out in a PerkinElmer GeneAmp PCR system 2400 instrument with reaction mixtures $(50 \mu \mathrm{l})$ containing $100 \mathrm{ng}$ of $T$. thermophilus RQ-1 DNA, as described previously (Silva et al. 2003).

Expression and purification of the recombinant enzymes

A clone bearing pKKTPS was grown in YT medium at $37^{\circ} \mathrm{C}$ to overexpress the recombinant TPS enzyme. Ampicillin was added at a final concentration of $100 \mu \mathrm{g} /$ $\mathrm{ml}$ for selection of plasmids pKKTPS, and cloramphenicol was added at a final concentration of $50 \mu \mathrm{g} / \mathrm{ml}$ to select for the plasmid with the genes for the rare tRNAs. The E. coli clone was grown until it reached a turbidity (O.D $\mathrm{D}_{610}$ ) of about 1.0, induced with $0.5 \mathrm{mM}$ isopropyl$\beta$-D-thiogalactopyranoside (IPTG) and grown further for $12 \mathrm{~h}$. Cells were harvested by centrifugation $(7,000 \mathrm{~g}$, $\left.10 \mathrm{~min}, 4^{\circ} \mathrm{C}\right)$. The pellet was resuspended in Tris- $\mathrm{HCl}$ $(20 \mathrm{mM}, \mathrm{pH} 7.6)$ containing DNase I $(10 \mu \mathrm{g})$ and protease inhibitors, disrupted, and centrifuged to remove cell debris (Silva et al. 2003). The cell-free extracts were heated for $20 \mathrm{~min}$ at $70^{\circ} \mathrm{C}$ to denature and precipitate the majority of the host proteins and then centrifuged 
$\left(25,000 \mathrm{~g}, 30 \mathrm{~min}, 4^{\circ} \mathrm{C}\right)$. The resulting supernatant was filtered through $0.22-\mu \mathrm{m}$-pore-size filters (Schleider and Schuell) and sequentially applied to two Q-Sepharose fast-flow columns (Hi-Load 16/10) equilibrated with $20 \mathrm{mM}$ Tris- $\mathrm{HCl}(\mathrm{pH}$ 7.6). Elution was carried out at a constant flow of $3 \mathrm{ml} / \mathrm{min}$ with linear $\mathrm{NaCl}$ gradient $(0.0-1.0 \mathrm{M})$ in the same buffer. The fractions showing TPS activity were pooled, concentrated, and loaded on a Superose-12 HR (10/30) column equilibrated with Tris$\mathrm{HCl} 50 \mathrm{mM}(\mathrm{pH} 7.6)$ containing $150 \mathrm{mM} \mathrm{NaCl}$ and eluted with a flow rate of $0.3 \mathrm{ml} / \mathrm{min}$. The fractions containing the pure TPS were pooled, concentrated, and stored at $-20^{\circ} \mathrm{C}$.

To overexpress the recombinant GST-tagged TPP, the clone bearing pTRC99A-GSTPP was grown as described for the clone bearing pKKTPS, induced with IPTG, and grown further for $6 \mathrm{~h}$. Cells were harvested by centrifugation $\left(7,000 \mathrm{~g}, 10 \mathrm{~min}, 4^{\circ} \mathrm{C}\right)$. The pellet was resuspended in PBS (pH 7.3, $140 \mathrm{mM} \mathrm{NaCl}$, $2.7 \mathrm{mM} \mathrm{KCl}, 10 \mathrm{mM} \mathrm{Na} \mathrm{HPO}_{4}, 1.8 \mathrm{mM} \mathrm{KH}_{2} \mathrm{PO}_{4}$ ) containing DNase $\mathrm{I}$ and the protease inhibitors as described above. The cell suspension was disrupted, centrifuged, and filtered, as described above. After filtration, the supernatant was loaded on a GSTPrep FF $16 / 10$ column at a constant flow rate of $2 \mathrm{ml} / \mathrm{min}$ and eluted with $50 \mathrm{mM}$ Tris- $\mathrm{HCl}(\mathrm{pH} 8.0)$ containing $10 \mathrm{mM}$ reduced glutathione at a constant flow rate of $4 \mathrm{ml} / \mathrm{min}$. The eluted fractions containing the fusion protein were pooled and treated with thrombin protease $\left(40 \mathrm{U} / \mathrm{mg}\right.$ protein) for $16 \mathrm{~h}$ at $22^{\circ} \mathrm{C}$. The fraction was applied to a Q-Sepharose fast flow column (Hi-Load 16/10) equilibrated with $20 \mathrm{mM}$ Tris- $\mathrm{HCl}$ $(\mathrm{pH}$ 7.6), and then eluted with a linear $\mathrm{NaCl}$ gradient $(0.0-1.0 \mathrm{M})$ in the same buffer to separate the GST and thrombin protease from TPP. The fractions containing the pure TPP were pooled, concentrated, and stored at $-20^{\circ} \mathrm{C}$.

Enzyme assays during purification of the proteins

TPS and TPP activities were confirmed in cell-free extracts of E. coli containing pKKTPS or pTRC99AGSTPP and during the fast protein liquid chromatography as follows. TPS and TPP activities were detected in reaction mixtures $(100 \mu \mathrm{l})$ that contained $10 \mu \mathrm{l}$ cellfree extract or $25 \mu$ l eluted fraction, $25 \mathrm{mM} \mathrm{MgCl}$ in $25 \mathrm{mM}$ Tris- $\mathrm{HCl}(\mathrm{pH} \mathrm{7.0})$, and $2 \mathrm{mM}$ of the corresponding substrates (UDPG and G6P for TPS or T6P for TPP). The reaction mixtures were incubated at $70^{\circ} \mathrm{C}$ for $15 \mathrm{~min}$ and then cooled on ice. The product of TPS reaction was incubated for additional 15 min with $2 \mathrm{U}$ of alkaline phosphatase (Sigma-Aldrich) at $37^{\circ} \mathrm{C}$ to form trehalose. The products of the reactions were visualized by thin-layer chromatography (TLC), on a Silica Gel 60 plate (Merck). The solvent system used was composed of butanol:ethanol:water $(5: 3: 2, \mathrm{v} / \mathrm{v})$, and the compounds were visualized by charring with $\alpha$-naphtol-sulfuric acid solution (Silva et al. 2003). Trehalose, T6P, UDPG, and
G6P were used as standards. Cell extracts from E. coli containing the plasmids without the inserts were also incubated in the same conditions, as negative controls.

\section{Properties of the recombinant TPS}

Several sugar nucleotides were tested as possible sugar donors, namely ADP-glucose (ADPG), GDP-glucose (GDPG), TDP-glucose (TDPG), UDPG, ADPmannose, GDP-mannose, UDP-mannose, and UDPgalactose. The activity of TPS for CDP-glucose was not examined, because it was not commercially available. We examined G6P, glucose-1,6-bisphosphate, mannose6-phosphate, and fructose-6-phosphate, as sugar acceptors. The reaction mixtures containing $4 \mathrm{mM}$ of each substrate in $25 \mathrm{mM}$ of Tris- $\mathrm{HCl}(\mathrm{pH} 7.0)$ and $25 \mathrm{mM}$ $\mathrm{MgCl}_{2}$ were incubated with $0.3 \mu \mathrm{g}$ of pure TPS at $80^{\circ} \mathrm{C}$ for $30 \mathrm{~min}$, followed by dephosphorylation at $37^{\circ} \mathrm{C}$ for 15 min with $2 \mathrm{U}$ of alkaline phosphatase. Samples were examined for the formation of products by TLC.

We characterized TPS, except for the determination of the kinetic parameters $\left(K_{\mathrm{m}}\right.$ and $\left.V_{\max }\right)$, using the following protocol. The reactions were initiated by the addition of $0.05 \mu \mathrm{g}$ of TPS to the reaction mixtures containing the appropriate buffer and $16 \mathrm{mM} \mathrm{G6P,} 8.0 \mathrm{mM}$ UDPG and an excess of TPP $(1.2 \mu \mathrm{g})$ to ensure complete dephosphorylation of T6P. The release of free phosphate was measured by the Ames reaction (Ames 1966). Since we perceived that $T$. thermophilus RQ-1 TPP dephosphorylated G6P, a parallel reaction mixture of the same composition as described above, without TPS, was incubated under the same conditions. Free phosphate from the dephosphorylation of G6P by TPP was subtracted from the total free phosphate obtained in the reaction mixture containing the two enzymes (TPS and TPP). The reaction mixtures were also spotted on TLC plates to confirm that the dephosphorylation of T6P was complete. The formation of glucose was determined to confirm that free glucose, resulting from the activity of TPP on G6P, was equal in reaction tubes with TPP alone or with TPP and TPS. Glucose was quantified enzymatically using the glucose oxidase assay kit (Sigma-Aldrich) as recommended by the manufacturer.

The effect of $\mathrm{pH}$ on TPS activity was determined in $25 \mathrm{mM}$ morpholineethanesulfonic acid (MES) buffer (pH 5.0-6.0), Bis-Tris-propane buffer ( $\mathrm{pH}$ 6.0-9.0) and $N$-tris(hydroxymethyl)-methyl-3-aminopropanesulfonic acid (TAPS) buffer ( $\mathrm{pH} \mathrm{8.0-9.0).} \mathrm{All} \mathrm{pH}$ values were measured at room temperature $\left(25^{\circ} \mathrm{C}\right)$; correct $\mathrm{pH}$ values at $80^{\circ} \mathrm{C}$ were calculated by using the conversion factor, $\Delta p K_{\mathrm{a}} / \Delta T\left({ }^{\circ} \mathrm{C}\right)=-0.011$ for MES, -0.015 for Bis-Tris propane, and -0.027 for TAPS.

The reaction mixtures to examine the effect of cations on enzyme activity, contained $25 \mathrm{mM}$ Tris- $\mathrm{HCl}(\mathrm{pH} 7.0)$ supplemented with $0.02,0.2,2.0,20$, and $200 \mathrm{mM}$ of the cation to be tested $\left(\mathrm{Mg}^{2+}, \mathrm{Co}^{2+}, \mathrm{Ca}^{2+}, \mathrm{Cu}^{2+}, \mathrm{Ba}^{2+}\right.$, $\mathrm{Sr}^{2+}$, and $\mathrm{Zn}^{2+}$ ) or did not contain any addition. Assays were performed at $80^{\circ} \mathrm{C}$. 
To determine the kinetic parameters of TPS, trehalose formation was assayed spectrophotometrically in a coupled enzyme assay where free UDP, released from glucose transfer from UDPG to G6P, was quantified by the conversion of phosphoenolpyruvate and UDP to pyruvate by pyruvate kinase and the conversion of pyruvate to lactate by lactate dehydrogenase (Pan et al. 2002). In one set of reactions, UDPG was varied between 0.1 and $8.0 \mathrm{mM}$, while $16.0 \mathrm{mM}$ glucose-6-phosphate was maintained constant to assess the rate dependence of recombinant TPS on UDPG. In another set of reactions, 0.1$8.0 \mathrm{mM}$ G6P plus $8.0 \mathrm{mM}$ UDPG were used to determine the rate dependence of the recombinant TPS on G6P.

The reactions were performed at $80^{\circ} \mathrm{C}$ in $25 \mathrm{mM}$ Tris- $\mathrm{HCl}$ ( $\mathrm{pH} \mathrm{7.0)}$ with $25 \mathrm{mM} \mathrm{MgCl}_{2}$, stopped by cooling in ethanol ice and freeze drying. The amount of free UDP was determined by resuspending the lyophilized material in $100 \mu \mathrm{l}$ deionized water to which $0.15 \mathrm{mM}$ NADH, $0.4 \mathrm{mM}$ phosphoenolpyruvate, $126 \mu \mathrm{g}$ of pyruvate kinase, and $20 \mu \mathrm{g}$ lactate dehydrogenase and $25 \mathrm{mM}$ Tris- $\mathrm{HCl}(\mathrm{pH} 7.0)$ with $25 \mathrm{mM}$ $\mathrm{MgCl}_{2}$ were added to a final volume of $1 \mathrm{ml}$. This reaction mixture was incubated at $30^{\circ} \mathrm{C}$, and the rate of NADH oxidation was measured at $\mathrm{A}_{340} \mathrm{~nm}$.

Properties of the recombinant TPP

G6P, glucose-1,6-bisphosphate, fructose-6-P, mannose6-P, T6P, UDPG, ADPG, GDPG, and TDPG (SigmaAldrich) were examined as possible substrates in a mixture containing $5.0 \mathrm{mM}$ of each substrate, with $0.3 \mu \mathrm{g}$ pure recombinant TPP, $25 \mathrm{mM}$ Tris- $\mathrm{HCl}$ (pH 7.0), and $25 \mathrm{mM} \mathrm{MgCl} 2$ at $70^{\circ} \mathrm{C}$ for $30 \mathrm{~min}$, followed by TLC analysis. The enzymatic activity of TPP was measured by determining the release of inorganic phosphate (Ames 1966).

The temperature profile was determined between 30 and $90^{\circ} \mathrm{C}$. The assay was performed in $50 \mu \mathrm{l} 25 \mathrm{mM}$ Tris- $\mathrm{HCl}$ ( $\mathrm{pH} 7.0$ ), $25 \mathrm{mM} \mathrm{MgCl}$, and $4 \mathrm{mM}$ T6P. Reactions were initiated by the addition of $0.06 \mu \mathrm{g}$ of TPP and were stopped at different times by cooling in ethanol ice. The effect of cations was determined at $70^{\circ} \mathrm{C}$ in $25 \mathrm{mM}$ Tris-HCl (pH 7.0) where $\mathrm{Mg}^{2+}, \mathrm{Co}^{2+} ; \mathrm{Ca}^{2+}$, $\mathrm{Cu}^{2+}, \mathrm{Ba}^{2+}, \mathrm{Sr}^{2+}$, and $\mathrm{Zn}^{2+}$ were added at appropriate concentrations; activity was also examined without the addition of cations.

The effect of $\mathrm{pH}$ on TPP activity was determined in $25 \mathrm{mM}$ acetate buffer ( $\mathrm{pH} 4.0-5.5), 25 \mathrm{mM}$ Tris- $\mathrm{HCl}$ buffer (pH 6.0-7.5), and Bis-Tris-propane buffer ( $\mathrm{pH}$ 6.0-9.0). All $\mathrm{pH}$ values were measured at room temperature $\left(25^{\circ} \mathrm{C}\right) ; \mathrm{pH}$ values at $70^{\circ} \mathrm{C}$ were calculated using the conversion factor, $\Delta p K_{\mathrm{a}} / \Delta T\left({ }^{\circ} \mathrm{C}\right)=-0.03$ for Tris- $\mathrm{HCl}$, and -0.015 for Bis-Tris propane.

Kinetic parameters of TPP were determined in reaction mixtures containing trehalose-6-phosphate $(0.1-6.0 \mathrm{mM})$ in $25 \mathrm{mM}$ Tris- $\mathrm{HCl}$ and $2 \mathrm{mM} \mathrm{MgCl} 2$, at $70^{\circ} \mathrm{C}$.
Other experimental procedures

To assess the thermal stability of TPS and TPP, protein solutions $(0.6 \mathrm{mg} / \mathrm{ml})$ were incubated at different temperatures in $25 \mathrm{mM}$ Tris- $\mathrm{HCl}(\mathrm{pH} \mathrm{7.0)}$. At appropriate times, samples were withdrawn and immediately examined for residual activities. TPS residual activities were determined at $80^{\circ} \mathrm{C}$ in a reaction mixture containing $25 \mathrm{mM}$ Tris- $\mathrm{HCl}$ (pH 7.0) with $25 \mathrm{mM} \mathrm{MgCl}_{2}$, and TPP residual activities were determine at $70^{\circ} \mathrm{C}$ in a reaction mixture containing $25 \mathrm{mM}$ Tris- $\mathrm{HCl}(\mathrm{pH} 7.0)$ and $2 \mathrm{mM} \mathrm{MgCl}_{2}$.

All experiments used to determine the properties of the recombinant enzymes were performed, at least, in duplicate. The protein contents of the samples were determined by the Bradford assay (Bradford 1976).

\section{Results}

Cloning of the ots $A$ and ots $B$ genes, functional overexpression in Escherichia coli, and purification of recombinant enzymes

The ots $A$ (encoding TPS) and ots $B$ (encoding TPP) genes of $T$. thermophilus RQ-1 were cloned from a gene library (Silva et al. 2003). Activity assays carried out in cell extracts of Escherichia coli clones containing plasmids pKKTPS or pTRC99A-GSTPP revealed that recombinant TPS was responsible for the conversion of UDPG and G6P into T6P, and that recombinant TPP dephosphorylated T6P to trehalose at $70^{\circ} \mathrm{C}$, whereas control E. coli bearing empty pKK223-3 or pTRC99A had no activity at this temperature (results not shown). SDS-PAGE analysis of crude extracts of XL1-blue clones showed weak expression bands as compared to the control cell extracts bearing empty vectors. Higher expression levels were achieved with BL21-Rosetta clones expressing tRNA genes for the rare codons.

The purification of the recombinant TPS was straightforward (Fig. 1a). However, we were unable to purify the recombinant TPP, using the same procedure and had to create a GST-TPP fusion protein followed by purification on a GSTprepFF affinity column chromatography (Fig. 1b). The recombinant TPS and TPP were nearly homogeneous and had a molecular mass of 52 and $26 \mathrm{kDa}$, as judged by SDS-PAGE, respectively.

\section{Catalytic properties of TPS}

The enzyme was specific for glucose diphosphate nucleosides; ADPG, GDPG, TDPG, or UDPG served as glucosyl donors. The enzyme was most active with UDPG $(149.6 \mu \mathrm{mol} / \mathrm{min} \mathrm{mg})$, followed by TDPG $(106.7 \mu \mathrm{mol} / \mathrm{min} \mathrm{mg})$, ADPG $(95.0 \mu \mathrm{mol} / \mathrm{min} \mathrm{mg})$, and GDPG $(20.6 \mu \mathrm{mol} / \mathrm{min} \mathrm{mg})$. G6P was the only glucosyl acceptor for any of these donors. G6P could not be replaced by mannose-6-P, fructose-6-P, or 

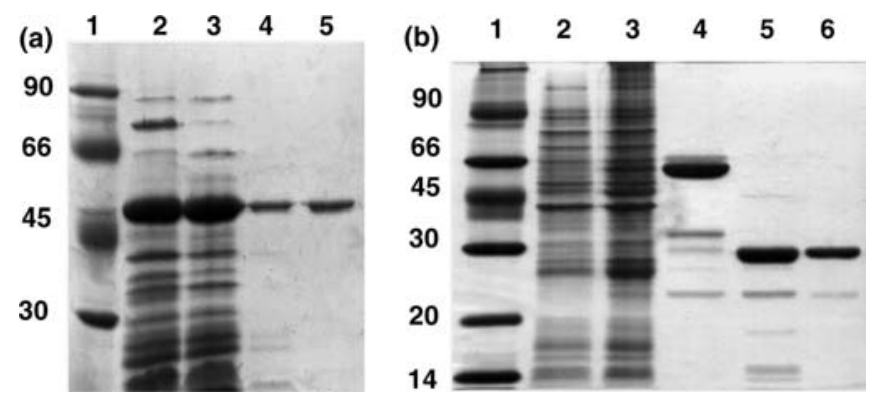

Fig. 1 SDS-PAGE of the fractions obtained during the purification of the recombinant enzymes. a Purification of recombinant trehalose-phosphate synthase (TPS). Lane 1 Protein standards, lane 2 crude extract after heat treatment, lane 3 pooled fractions after first Q-Sepharose column, lane 4 pooled fractions after second Q-Sepharose column, lane 5 pooled fractions after Superose-12 column. b Purification of recombinant trehalose-phosphate phosphatase (TPP). Lane 1 Protein standards, lane 2 crude extract of cells before isopropyl- $\beta$-D-thiogalactopyranoside (IPTG) induction, lane 3 crude extract after IPTG induction, lane 4 fraction eluted from GSTFF column, lane 5 fraction after thrombin treatment, lane 6 fraction eluted from Q-Sepharose column

glucose-1,6-P (results not shown). The effect of increasing concentrations of UDPG, in the presence of saturating levels of G6P $(16 \mathrm{mM})$, or increasing concentrations of G6P in the presence of saturating levels of UDPG $(8 \mathrm{mM})$ on the rate of TPS indicated that the enzyme exhibited Michaelis-Menten kinetics (Fig. 2). The Lineweaver-Burk plot of this data indicated a $K_{\mathrm{m}}$ value for UDPG of $0.5 \mathrm{mM}$ (Fig. 2a, inset) and a $K_{\mathrm{m}}$ value for G6P of $0.8 \mathrm{mM}$ (Fig. 2b, inset). The $V_{\max }$ for TPS was $204 \mu \mathrm{mol} / \mathrm{min} \mathrm{mg}$ (Table 1 ).

The method used to examine the temperature profile, thermostability, $\mathrm{pH}$ range, and cation dependence of TPS relied on the quantification of free phosphate released by the action of TPP on T6P and was based on Empadinhas et al. (2003), who determined enzyme parameters for mannosylphosphoglycerate synthase on the specific release of phosphate from mannosylphos-

Fig. 2 Rate dependence of the recombinant TPS on uridinediphosphoglucose (UDPG) (a) and on glucose-6-phosphate (G6P) concentrations (b), and the rate dependence of the recombinant TPP on trehalose-6-phosphate (T6P) concentration (c). The insets show double-reciprocal plots of the rate against the corresponding substrate concentration. The assay mixtures contained 0.05 and $0.06 \mu \mathrm{g}$ of recombinant TPS and TPP, respectively phoglycerate by mannosylphosphoglycerate phosphatase. However, TPP also had some activity towards G6P that increased when NDP-glucose (NDPG) was added to the reaction mixture. To insure that the amount of free phosphate subtracted from the dephosphorylation of G6P by TPP was accurate, the formation of glucose was also measured in both reaction tubes (TPP alone or TPP in the presence of TPS). The glucose produced under both conditions was the same and was equal to the amount of free phosphate measured when NDPG and G6P were incubated with TPP (results not shown).

TPS had no activity at $30^{\circ} \mathrm{C}$, but increased dramatically above $40^{\circ} \mathrm{C}$ with an optimum at $98^{\circ} \mathrm{C}$ (Fig. 3). At $102^{\circ} \mathrm{C}$, TPS still had $80 \%$ of the total activity. An activation energy of $47 \mathrm{~kJ} / \mathrm{mol}$ was calculated from the linear part of the Arrhenius plot (Fig. 3, inset) between 40 and $95^{\circ} \mathrm{C}$. The enzyme had extremely high stability against thermal inactivation (Fig. 4a), with a half-life of $31 \mathrm{~min}$ at $100^{\circ} \mathrm{C}$ (Table 1$)$. Within the $\mathrm{pH}$ range examined, the activity of the enzyme was maximal near pH 6.0.

Divalent cations were not required for activity of TPS; however, the presence of $\mathrm{Mg}^{2+}$ or $\mathrm{Co}^{2+}$ stimulated enzyme activity. The specific activity of TPS in the absence of cations was $47.9 \mu \mathrm{mol} / \mathrm{min} \mathrm{mg}(32.0 \%$ of maximal activity). The maximum activity was obtained with $20 \mathrm{mM}$ of $\mathrm{Mg}^{2+}$, but $0.2 \mathrm{mM} \mathrm{Co}^{2+}$ produced $61 \%$ of the activity obtained with the $\mathrm{Mg}^{2+} \cdot \mathrm{Co}^{2+}$ above $20 \mathrm{mM}$ inhibited TPS. $\mathrm{Mn}^{2+}$ had no effect on activity between 0.02 and $2.0 \mathrm{mM}$, but was inhibitory above $20 \mathrm{mM}$. All the other cations tested $\left(\mathrm{Ca}^{2+}, \mathrm{Cu}^{2+}, \mathrm{Ba}^{2+}\right.$, $\mathrm{Sr}^{2+}$, and $\mathrm{Zn}^{2+}$ ) inhibited TPS activity at the concentrations tested (results not shown).

\section{Catalytic properties of TPP}

The recombinant TPP was relatively specific for T6P, but also had low activity towards G6P (3.1\%). Furthermore, all glucose diphosphate nucleosides examined lead to an increase in the activity of TPP for G6P. The addition of ADPG, GDPG, TDPG, or UDPG (all at $5 \mathrm{mM}$ ) caused an increase in the activity of TPP towards G6P to $4.5,3.6,4.6$ and $10 \%$ of the total activity for T6P, respectively. The recombinant TPP did not dephosphorylate any of the glucose diphosphate nucle-
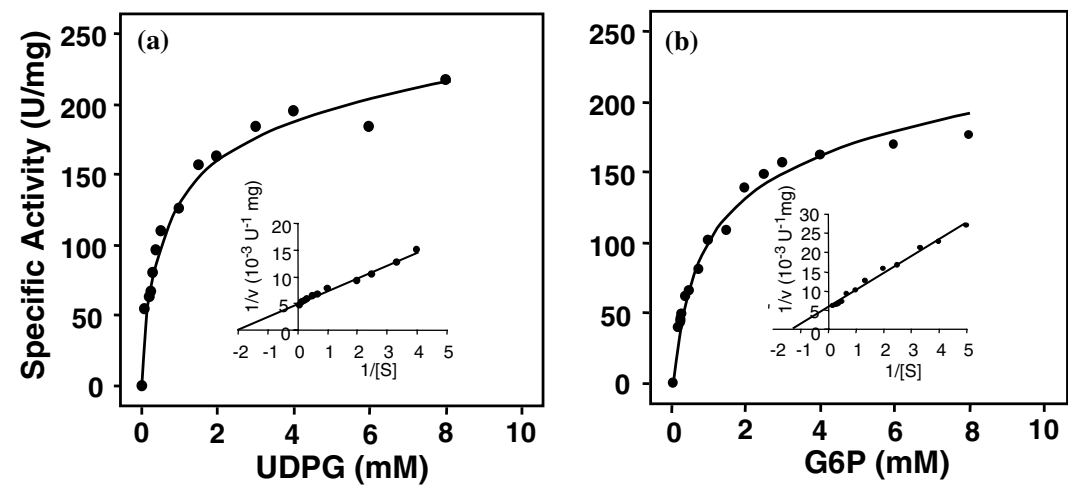

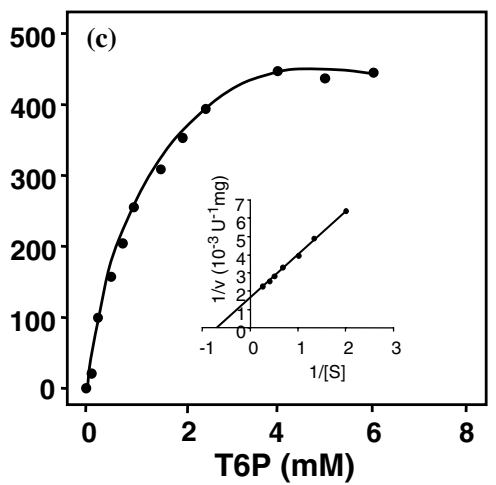


Table 1 Biochemical properties of the enzymes and kinetic parameters for the substrates involved in the synthesis of trehalose in Thermus thermophilus RQ-1 via trehalose-phosphate synthase (TPS)/trehalose-phosphate phosphatase (TPP)

\begin{tabular}{lcc}
\hline Property & Values $^{\mathrm{a}}$ & \\
\cline { 2 - 3 } & TPS & TPP \\
\hline Optimum temperature & 98 & 70 \\
for activity $\left({ }^{\circ} \mathrm{C}\right)$ & & $\sim 7$ \\
Optimum pH for activity & $\sim 6$ & 57.4 \\
Activation energy $(\mathrm{kJ} / \mathrm{mol})$ & 47.0 & 161 \\
Half life $(\mathrm{min})$ & 193 & 120 \\
$80^{\circ} \mathrm{C}$ & 54 & 40 \\
$90^{\circ} \mathrm{C}$ & 31 & - \\
$100^{\circ} \mathrm{C}$ & & - \\
$K_{\mathrm{m}}(\mathrm{mM})$ & 0.5 & 1.5 \\
UDP-glucose & 0.8 & 625 \\
Glucose-6-P & 204 & \\
Trehalose-6-P & & \\
$V_{\text {max }}(\mu \mathrm{mol} / \mathrm{min} \mathrm{mg})$ & & \\
\hline
\end{tabular}

${ }^{a}$ Data are the mean values of, at least, two independent experiments

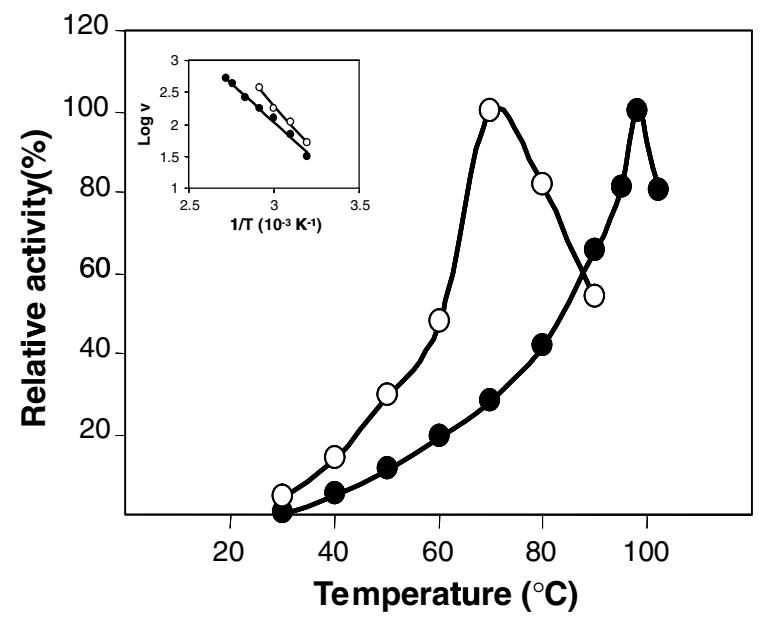

Fig. 3 Temperature dependence of the activity of recombinant TPS (filled circle) and the recombinant TPP (open circle). The enzyme activities were determined at temperatures between 30 and $102^{\circ} \mathrm{C}$. The inset represents the Arrhenius plot of the data between 40 and $95^{\circ} \mathrm{C}$

osides. TPP exhibited typical Michaelis-Menten kinetics. The Lineweaver-Burk plot indicated a $K_{\mathrm{m}}$ value of $1.5 \mathrm{mM}$ (Fig. 2c). For this enzyme, a $V_{\max }$ of $625 \mu \mathrm{mol} /$ min $\mathrm{mg}$ was estimated (Table 1).

Trehalose-phosphate phosphatase had maximal activity at $70^{\circ} \mathrm{C}$ and at $90^{\circ} \mathrm{C}$ still retained $45 \%$ of the maximum activity (Fig. 3). From the Arrhenius plot between 50 and $80^{\circ} \mathrm{C}$, an activation energy of $57.4 \mathrm{~kJ} /$ mol was calculated. The half-lives determined at 80,90 , and $100^{\circ} \mathrm{C}$ were 161,120 , and $40 \mathrm{~min}$ (Fig. $4 \mathrm{~b}$, Table 1). The optimum $\mathrm{pH}$ for activity was near 7.0. The recombinant TPP did not require divalent cations for activity, but was also stimulated by $\mathrm{Mg}^{2+}$ or $\mathrm{Co}^{2+}$.
The specific activity of TPP without cations was $144.6 \mu \mathrm{mol} / \mathrm{min} \mathrm{mg}(32.5 \%$ of maximal activity); the maximum activity for TPP was obtained with either $2.0 \mathrm{mM} \mathrm{Co}^{2+}(100 \%)$ or $\mathrm{Mg}^{2+}(97 \%)$. Manganese had no effect at concentrations equal or lower than $2.0 \mathrm{mM}$, but higher concentrations inhibited activity. Other divalent cations, namely $\mathrm{Ca}^{2+}, \mathrm{Cu}^{2+}, \mathrm{Ba}^{2+}, \mathrm{Sr}^{2+}$, and $\mathrm{Zn}^{2+}$ inhibited TPP activity (results not shown).

\section{Discussion}

Unlike the majority of TPSs of different origins characterized so far, the TPS of Thermus thermophilus RQ-1 was rather non-specific for glucosyl donors, using UDPG, TDPG, ADPG, and GDPG. The TPS of Escherichia coli, for example, uses UDPG but not ADPG (Giæver et al. 1988). The only example of a TPS having a low substrate specificity was reported for Mycobacterium tuberculosis, which can use all natural glucose diphosphate nucleosides (Pan et al. 2002).

The T. thermophilus RQ-1 TPP is specific for T6P, but is also slightly active for the dephosphorylation of G6P. Surprisingly, NDPG enhanced the activity of TPP towards G6P. We do not have an explanation for this observation, but a similar phenomenon has been observed before; the TPP from the blow fly Phormia regina also hydrolizes G6P (7\% of its activity towards T6P), and this activity was stimulated by the presence of trehalose which interacts with the active site for G6P, at low substrate concentration (Friedman 1971).

Some enzymes from thermophiles have higher $K_{\text {cat }}$ than their mesophilic counterparts do (Thomas and Scopes 1998). Indeed, the $K_{\mathrm{cat}}$ values of TPS and TPP of RQ-1 (176.9 and $271.7 \mathrm{~s}^{-1}$, respectively) are very high when compared to the values of TPS and TPP from $E$. coli (Seo et al. 2000). Moreover, the Thermus enzymes have also lower $K_{\mathrm{m}}$ values, meaning that these enzymes have higher catalytic efficiency, when compared to that from E. coli.

Both enzymes are stimulated by the presence of $\mathrm{Co}^{2+}$ or $\mathrm{Mg}^{2+}$, although $\mathrm{Co}^{2+}$ was less effective than $\mathrm{Mg}^{2+}$ in stimulating the activity of TPS. All TPSs examined have activity in the absence of divalent cations although most are stimulated by $\mathrm{Mg}^{2+}$ but not by $\mathrm{Co}^{2+}(\mathrm{Cabib}$ and Leloir 1958; Murphy and Wyatt 1965; Lapp et al. 1971; Killick 1979; Lippert et al. 1993). The activity of the Mycobacterium smegmatis TPS is stimulated by $\mathrm{Mg}^{2+}$ or $\mathrm{Co}^{2+}$ (Lapp et al. 1971). T. thermophilus RQ-1 TPP, unlike other TPPs that have been analyzed, does not require divalent cations for activity. (Friedman 1971; Klutts et al. 2003).

Of all the TPSs and TPPs examined, those of $T$. thermophilus RQ-1 have the highest optimum temperature for activity. The high temperature optima and the extremely high thermostability of these enzymes stem from the fact that the organism is thermophilic and temperature imposes constraints on proteins. All enzymes from Thermus spp. examined have high thermo- 
Fig. 4 Thermostability of the recombinant TPS (a) and TPP (b). The enzymes were incubated at $70^{\circ} \mathrm{C}$ (filled circle), $80^{\circ} \mathrm{C}$ (filled square), $90^{\circ} \mathrm{C}$ (filled triangle), and $100^{\circ} \mathrm{C}$ (filled inverted triangle). Samples were withdrawn at different incubation times and examined for residual activity at $80^{\circ} \mathrm{C}$ for TPS and $70^{\circ} \mathrm{C}$ for TPP
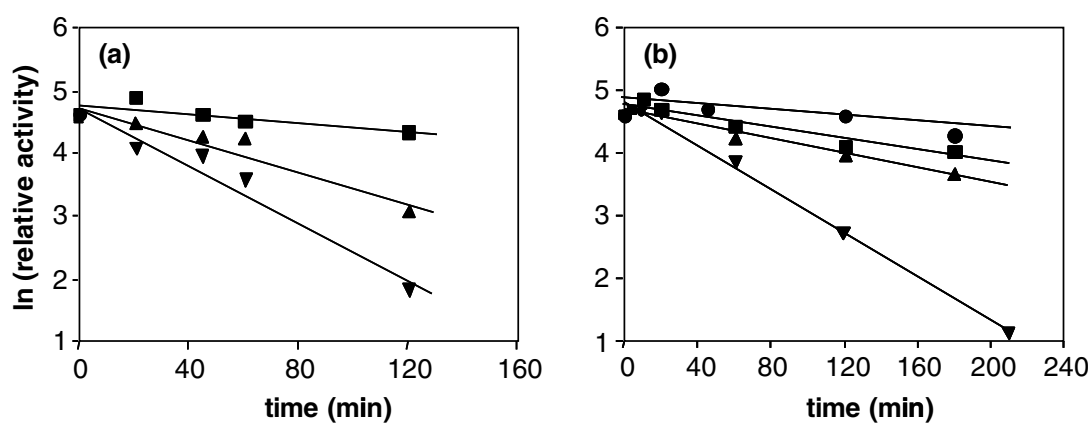

stability, as would be expected (Koyama and Furukawa 1990; Wang et al. 2003). The TPP from the mesophilic $M$. smegmatis, on the other hand, was completely inactivated after incubation for $0.5 \mathrm{~min}$ at $100^{\circ} \mathrm{C}$ (Klutts et al. 2003), and a mixture of TPS/TPP from E. coli retained only $3 \%$ of the original activity after incubation at $50^{\circ} \mathrm{C}$ for $30 \mathrm{~min}$ (Seo et al. 2000). The enhanced stability of enzymes at high temperature is the result of differences in specific amino acid composition (Vieille et al. 1996). The T. thermophilus RQ-1 TPS and TPP (GenPept accession numbers AAQ16095/16096) had lower frequency of glutamine (1.4- and 4.0-fold, respectively) than their counterparts did in E. coli. The frequency of asparagine was 2.9- and 5.0-fold lower than in the E. coli TPS and TPP. The decrease in the frequency of glutamine and asparagine is one of the distinctive characteristics of the enzymes of thermophilic origin and results from temperature-imposed restrictions (Vieille et al. 2001; Singer and Hickey 2003). Other amino acid substitutions contributing to high thermostability were the low cysteine of tryptophan synthetase from T. thermophilus HB27 (Koyama and Furukawa 1990) and the high alanine and proline content of $\beta$ glycosidase from Thermus strain HG102 (Wang et al. 2003). None of these trends was observed in T. thermophilus RQ-1 TPS and TPP. The relevance of the effect caused by an amino acid substitution depends on its location on the 3-D structure of the protein; thus, it is sometimes difficult to assign amino acid changes that contribute to thermostability by evaluation of the amino acid sequence only (Koyama and Furuwaka 1990).

The optimum temperature for activity of TPP is around $70^{\circ} \mathrm{C}$, while that of TPS is about $98^{\circ} \mathrm{C}$. However, the thermostability of the TPP is higher than the TPS. Other enzymes from (hyper)thermophiles have very high thermostability and relatively low optimal temperature for activity, indicating a partial independence between both parameters (Arnott et al. 2000).

Although other TPSs and TPPs from thermophilic organisms have been identified by sequence comparison in the genome databases there is, to our knowledge, no report of characterization of TPSs or TPPs from (hyper)thermophilic organisms. These two enzymes differ from mesophilic counterparts by their notable temperature optimum for activity and their extremely high thermostability.
Acknowledgements This research was funded by the European Commission 5th Framework Programme, project QLK3-CT-200000640, and FCT/FEDER projects PRAXIS/P/BIO/12082/1998 and POCTI $/ 35715 / \mathrm{BIO} / 2000$. Z. Silva acknowledges a Ph.D. grant from PRAXIS XXI (BD/21669/99).

\section{References}

Ames BN (1966) Assay of inorganic phosphate, total phosphate and phosphatases. Methods Enzymol 8:115-118

Arnott MA, Michael RA, Thompson CR, Hough DW, Danson MJ (2000) Thermostability and thermoactivity of citrate synthases from thermophilic and hyperthermophilic archaea, Thermoplasma acidophilum and Pyrococcus furiosus. J Mol Biol 304:657668

Bradford MM (1976) A rapid and sensitive method for the quantification of microgram quantities of protein utilizing the principle of protein-dye binding. Anal Biochem 72:248-254

Cabib E, Leloir L (1958) The biosynthesis of trehalose-phosphate. J Biol Chem 231:259-275

da Costa MS, Nobre MF, Rainey FA (2001) The genus Thermus. In: Boone DR, Castenholtz RW (eds) Bergey's manual of systematic bacteriology, vol. 1, 2nd edn. Springer, Berlin Heidelberg New York, pp 404-414

De Smet KAL, Weston A, Brown IN, Young DB, Robertson BD (2000) Three pathways for trehalose biosynthesis in mycobacteria. Microbiology 146:199-208

Elbein AD, Pan YT, Pastuszak I, Carroll D (2003) New insights on trehalose: a multifunctional molecule. Glycobiology 13:17-27

Empadinhas N, Albuquerque L, Henne A, Santos H, da Costa MS (2003) The bacterium Thermus thermophilus, like hyperthermophilic archaea, uses a two-step pathway for the synthesis of mannosylglycerate. Appl Environ Microbiol 69:3272-3279

Friedman S (1971) Interactions among sites responsible for trehalose-6-phosphate and trehalose-activated glucose-6-phosphate hydrolysis on trehalose phosphatase isolated from Phormia regina. J Biol Chem 246:4122-4130

Giæver HM, Styrvold OB, Kaasen I, Strøm AR (1988) Biochemical and genetic characterization of osmoregulatory trehalose synthesis in Escherichia coli. J Bacteriol 170:2841-2849

Killick KA (1979) Trehalose-6-phosphate synthase from Dyctiostelium discoideum: partial purification and the characterization of the enzyme from young sorocarps. 196:121-133

Klutts S, Pastuszak I, Edavana VK, Thampi P, Pan Y-T, Abraham EC, Carroll JD, Elbein AD (2003) Purification, cloning and properties of mycobacterial trehalose-phosphate phosphatase. J Biol Chem 278:2093-2100

Koyama Y, Furukawa K (1990) Cloning and sequence analysis of tryptophan synthetase genes of an extreme thermophile, Thermus thermophilus HB27: plasmid transfer from replica-plated Escherichia coli recombinant colonies to competent T. thermophilus cells. J Bacteriol 172:3490-3495

Lamosa P, Martins LO, da Costa MS, Santos H (1998) Effects of temperature, salinity, and medium composition on compatible 
solute accumulation by Thermococcus spp. Appl Environ Microbiol 64:3591-3598

Lapp D, Patterson BW, Elbein AD (1971) Properties of a trehalose phosphate synthase from Mycobacterium smegmatis. J Biol Chem 246:4567-4579

Leslie SB, Israeli E, Lighthart B, Crowe JH, Crowe LM (1995) Trehalose and sucrose protect both membranes and proteins in intact bacteria during drying. Appl Environ Microbiol 61:35923597

Lippert K, Galinski EA, Truper HG (1993) Biosynthesis and function of trehalose in Ectothiorhodospira halochloris. Antonie Van Leeuwenhoek 63:85-91

Marmur J (1961) A procedure for the isolation of deoxyribonucleic acid from microorganisms. J Mol Biol 3:208-218

Maruta K, Nakada T, Kubota M, Chaen H, Sugimoto T, Kurimoto M, Tsujisaka Y (1995) Formation of trehalose from maltooligosaccharides by a novel enzymatic system. Biosci Biotech Biochem 59:1829-1834

Maruta K, Hattori K, Nakada T, Kubota M, Sugimoto T, Kurimoto M (1996a) Cloning and sequencing of trehalose biosynthesis genes from Arthrobacter sp. Q36. Biochim Biophys Acta 1289:10-13

Maruta K, Hattori K, Nakada T, Kubota M, Sugimoto T, Kurimoto M (1996b) Cloning and sequencing of trehalose biosynthesis genes from Rhizobium sp. M-11. Biosci Biotechnol Biochim 60:717-720

Maruta K, Hattori K, Nakada T, Kubota M, Chaen H, Fukuda S, Sugimoto T, Kurimoto M (1996c) Cloning and sequencing of cluster of genes encoding novel enzymes of trehalose biosynthesis from thermophilic archaebacterium Sulfolobus acidocaldarius. Biochim Biophys Acta 1291:177-181

Mikkat S, Effmert U, Hagemann M (1997) Uptake and use of the osmoprotective compounds trehalose, glucosylglycerol, and sucrose by the cyanobacterium Synechocystis sp. PCC6803. Arch Microbiol 167:112-118

Mitchell DA, Marshall TK, Deschenes RJ (1993) Vectors for the inducible overexpression of gluthathione S-transferase fusion proteins in yeast. Yeast 9:715-723

Murphy TA, Wyatt GR (1965) The enzymes of glycogen and trehalose synthesis in silk moth fat body. J Biol Chem 240:15001508

Nunes OC, Manaia CM, da Costa MS, Santos H (1995) Compatible solutes in the thermophilic bacteria Rhodothermus marinus and "Thermus thermophilus". Appl Environ Microbiol 61:2351-2357

Pan YT, Carroll JD, Elbein AD (2002) Trehalose-phosphate synthase of Mycobacterium tuberculosis: cloning, expression and purification of the recombinant enzyme. Eur $\mathbf{J}$ Biochem 269:6091-6100

Reinders A, Bürckert N, Hohmamm S, Thevelein JM, Boller T, Wiemken A, De Virgilio C (1997) Structural analysis of the subunits of the trehalose-6-phosphate synthase/phosphatase complex in Saccharomyces cerevisiae and their function during heat shock. Mol Microbiol 24:687-695

Santos H, da Costa MS (2002) Compatible solutes of organisms that live in hot saline environments. Environ Microbiol 4:501509

Seo HS, Koo YJ, Lim JY, Song JT, Kim CH, Kim JK, Lee JS, Choi YD (2000) Characterization of bifunctional enzyme fusion of trehalose-6-phosphate synthase and trehalose-6-phosphate phosphatase of Escherichia coli. Appl Environ Microbiol 66:2484-2490

Silva Z, Alarico S, Nobre A, Horlacher R, Marugg J, Boos W, Mingote AI, da Costa MS (2003) Osmotic adaptation of Thermus thermophilus RQ-1: a lesson from a mutant deficient in the synthesis of trehalose. J Bacteriol 185:5943-5952

Singer GA, Hickey DA (2003) Thermophilic prokaryotes have characteristic patterns of codon usage, amino acid composition and nucleotide content. Gene 317:39-47

Thomas TM, Scopes RK (1998) The effects of temperature on the kinetics and stability of mesophilic and thermophilic 3-phosphoglycerate kinases. Biochem J 330:1087-1095

Tsusaki K, Nishimoto T, Nakada T, Kubota M, Chaen H, Sugimoto T, Kurimoto M (1996) Cloning and sequencing of trehalose synthase gene from Pimelobacter sp. R48. Biochim Biophys Acta 1290:1-3

Tsusaki K, Nishimoto T, Nakada T, Kubota M, Chaen H, Fukuda S, Sugimoto T, Kurimoto M (1997) Cloning and sequencing of trehalose synthase gene from Thermus aquaticus ATCC 33923. Biochim Biophys Acta 1334:28-32

Vieille C, Burdette DS, Zeikus JG (1996) Thermozymes. Biotechnol Annu Rev 2:1-83

Vieille C, Epting KL, Kelly RM, Zeikus JG (2001) Bivalent cations and amino-acid composition contribute to the thermostability of Bacillus licheniformis xylose isomerase. Eur $\mathbf{J}$ Biochem 268:6291-6301

Wang X, He X, Yang S, An X, Chang W, Liang D (2003) Structural basis for thermostability of $\beta$-glycosidase from the thermophilic eubacterium Thermus nonproteolyticus HG102. J Bacteriol 185:4248-4255

White O, Eisen JA, Heidelberg JF, Hickey EK, Peterson JD, Dodson RJ, Haft DH, Gwinn ML, Nelson WC, Richardson DL, Moffat KS, Qin H, Jiang L, Pamphile W, Crosby M, Shen M, Vamathevan JJ, Lam P, Mc Donald L, Utterback T, Zalewski C, Makarova KS, Aravind L, Daly MJ, Fraser CM, et al (1999) Genome sequence of the radioresistant bacterium Deinococcus radiodurans $\mathrm{R} 1$. Science 286:1571-1577

Wolf A, Krämer R, Morbach S (2003) Three pathways for trehalose metabolism in Corynebacterium glutamicum ATCC 13032 and their significance in response to osmotic stress. Mol Microbiol 49:1119-1134 